ISSN: $1896-4087$

DOI: http://dx.doi.org/10.21784/ZC.2018.010

\title{
Europejska Agencja Kosmiczna
}

\author{
European Space Agency
}

\section{Streszczenie:}

Europejska Agencja Kosmiczna (ESA) jest organizacją międzynarodową zrzeszającą obecnie 22 państwa członkowskie. Agencja przyczynia się między innymi do wsparcia postępu technologii i usług satelitarnych. Polska dołączyła do ESA w listopadzie 2012 r., chociaż współpraca Polski z ESA trwała już znacznie wcześniej, na podstawie Umowy o współpracy w zakresie pokojowego wykorzystania przestrzeni kosmicznej. Bazując na literaturze polskiej oraz zagranicznej, w artykule zostały przedstawione najważniejsze zadania, zagadnienia organizacyjno-prawne, informacje na temat dotychczasowej działalności wraz z podstawowymi wiadomościami na temat członków tej organizacji międzynarodowej.

Słowa kluczowe: Europejska Agencja Kosmiczna, przestrzeń kosmiczna, Europejski program kosmiczny

\begin{abstract}
:
The European Space Agency (ESA) is currently an international organisation of 22 Member States. The Agency contributes, inter alia, to supporting the advancement of satellite technology and renders respective satellite services. Pursuant to the Peaceful Uses of Outer Space Agreement, Poland joined ESA in November 2012, although the cooperation between Poland and ESA had been continued much earlier. Drawing upon both Polish and foreign literature, the article refers to most important tasks, organizational and legal issues, information on the activities conducted so far, as well as basic information on the members of the international Agency.
\end{abstract}

Keywords: European Space Agency, space, European space program 


\section{Wprowadzenie}

Od czasu swojego ustanowienia Europejska Agencja Kosmiczna $\left(\right.$ ESA $\left.^{1}\right)$ zawsze koncentrowała się na możliwościach wykorzystania satelitów do obserwacji Ziemi. Obrazy satelitarne stanowią ważne narzędzia do realizacji różnorodnych celów naziemnych. Europejskie satelity meteorologiczne jako część globalnej sieci codziennie przyczyniają się do długo- i krótkoterminowego prognozowania pogody ${ }^{2}$. Inne satelity opracowane przez ESA odpowiadają za monitorowanie naszej planety, analizując różne zjawiska na lądzie i morzu, przykładowo takie jak niszczenie światowych lasów deszczowych i mas lodu polarnego ${ }^{3}$. Celem artykułu jest przedstawienie najważniejszych zadań i zagadnień organizacyjno-prawnych ESA. Zadanie to zostanie osiągnięte poprzez ukazanie działalności Agencji między innymi z perspektywy przeprowadzania wspólnego, europejskiego programu badania przestrzeni kosmicznej, a także wzmacniania postępu w krajach członkowskich. Dopełnienie omówienia ESA stanowić będą informacje na temat dotychczasowej działalności Agencji wraz z przedstawieniem podstawowych wiadomości na temat członków tej organizacji międzynarodowej.

Europejska Agencja Kosmiczna została utworzona na mocy Konwencji o utworzeniu Europejskiej Agencji Kosmicznej, podpisanej w Paryżu w dniu 30 maja 1975 roku, która weszła w życie w 1980 r., w wyniku połączenia Europejskiej Organizacji Badań Kosmicznych (ESRO) i Europejskiej Organizacji Rozwoju Rakiet Nośnych (ELDO) ${ }^{4}$. Siedziba Agencji znajduje się w Paryżu 5 . ESA jest organizacją międzynarodową zrzeszającą obecnie 22 państwa członkowskie. Koordynując zasoby finansowe i intelektualne swoich członków, organizacja ta może

\footnotetext{
${ }^{1}$ Ang. European Space Agency.

${ }^{2}$ L.Beckel (red.), Mega Cities: The European Space Agency's Contribution to a Better Understanding of a Global Challange, Salzburg 2002, s. 6.

${ }^{3}$ Ibidem.

${ }^{4}$ M. Drobysz, Komentarz do Traktatu ustanawiajacego Wspólnotę Europejska (art. 173), [w:] A. Wróbel (red.), Traktat o Unii Europejskiej, Traktat ustanawiający Wspólnotę Europejska z komentarzem, wyd. II, Warszawa 2006.

${ }^{5}$ I. Ridpath, A Dictionary of Astronomy, Oxford 2004, s. 152.
} 
podejmować programy i działania będące poza zakresem działania jednego państwa europejskiego ${ }^{6}$.

Mimo faktu, iż centrala ESA znajduje się w Paryżu, Agencja działa w sześciu ośrodkach. Oddziały zostały wyodrębnione mając na uwadze ich sfery działalności. Główny ośrodek o nazwie Europejskie Centrum Badań i Technologii Kosmicznych (ESTEC ${ }^{7}$ ) znajduje się w Noordwijk w Holandii, kolejny z nich o nazwie Europejskie Centrum Operacji Kosmicznych $\left(\mathrm{ESOC}^{8}\right)$ posiada swoją siedzibę w Darmstadt w Niemczech, Europejskie Centrum Obserwacji Ziemi (ESRIN $\left.{ }^{9}\right)$ mieści się we włoskim mieście Frascati, Europejskie Centrum Astronomiczne w Villanueva de la Canada $\left(\mathrm{ESAC}^{10}\right.$ ) posiada swoją siedzibę w Madrycie, kolejny z oddziałów to ośrodek brytyjski o nazwie Europejskie Centrum Aplikacji Kosmicznych i Telekomunikacji w Harwell (ECSAT ${ }^{11}$ ) w Oxfordshire, a w Niemczech mieści się również Europejskie Centrum Astronautów $\left(E C^{12}\right)$ w Kolonii ${ }^{13}$. Kosmodrom należący do ESA znajduje się w Kourou w Gujanie Francuskiej ${ }^{14}$. Zgodnie z przepisem art. 10 Konwencji z dnia 30 maja 1975 r. o utworzeniu Europejskiej Agencji Kosmicznej ${ }^{15}$, organami Agencji są Rada oraz dyrektor generalny wspierany przez personel.

\section{Cele Europejskiej Agencji Kosmicznej}

Sektor kosmiczny współcześnie postrzegany jest jako jedna z najbardziej innowacyjnych i zaawansowanych technologicznie dziedzin,

${ }^{6}$ www.esa.int/About_Us/Welcome_to_ESA/What_is_ESA, [dostęp: 02-03-2018].

${ }^{7}$ Ang. European Space Research and Technology Centre.

${ }^{8}$ Ang. European Space Operations Centre.

${ }^{9}$ Ang. European Space Research Institute.

${ }^{10}$ Ang. European Space Astronomy Centre.

${ }^{11}$ Ang. European Centre for Space Applications and Telecommunications.

${ }^{12}$ Ang. European Astronauts Centre.

${ }^{13}$ J. Mitton, A concise dictionary of astronomy, Nowy Jork 1991, s. 143; również: I. Ridpath, A Dictionary of Astronomy, Oxford: Oxford University Press 2004, s. 152, www.esa.int/pol/ESA_in_your_country/Poland/Poznaj_ESA, [dostęp: 27-02-2017].

${ }^{14}$ Ibidem.

${ }^{15}$ Convention for the establishment of a European Space Agency, www.download. esa.int/docs/LEX-L/ESA-Convention/20101200-SP-1317-EN_Extract_ESAConvention.pdf, [dostęp: 05-03-2018]. 
o ciągle rosnącym znaczeniu dla gospodarki europejskiej i światowej. Dlatego też tak ważne jest poznanie celu ESA, który został zapisany w Konwencji o jej utworzeniu.

Zgodnie z przepisem art. 2 Konwencji ${ }^{16}$ dążeniem Agencji jest zapewnienie i promowanie, wyłącznie w celach pokojowych, współpracy między państwami europejskimi w zakresie badań i technologii kosmicznych oraz ich zastosowań kosmicznych, w zamierzeniu ich wykorzystania do zadań naukowych i systemów operacyjnych związanych z zastosowaniami kosmicznymi.

Cel ten ma być osiągnięty poprzez wypracowanie i wdrożenie długoterminowej europejskiej polityki kosmicznej, zalecanie państwom członkowskim zadań w zakresie przestrzeni kosmicznej oraz uzgadnianie polityk państw członkowskich z innymi krajowymi i międzynarodowymi organizacjami oraz instytucjami. Będzie to możliwe także dzięki opracowaniu i wdrożeniu działań oraz programów w dziedzinie przestrzeni kosmicznej. Co więcej cel ESA wedle założeń Konwencji będzie realizowany poprzez koordynację europejskiego programu kosmicznego i krajowych programów kosmicznych oraz przy pomocy stopniowego i jak najpełniejszego włączania tych ostatnich do europejskiego programu kosmicznego, w szczególności w odniesieniu do rozwoju zastosowań satelitów. Ponadto Konwencja przewiduje opracowanie i wprowadzenie polityki przemysłowej właściwej dla jej programu oraz zalecenie Państwom Członkowskim spójnej polityki przemysłowej.

\section{Zadania}

Celem programów ESA jest zdobycie jak największej wiedzy na temat Ziemi, otaczającej jej przestrzeni, układu planetarnego, którego jest częścią, a także całego wszechświata ${ }^{17}$. Stanowią one wsparcie dla postępu technologii i usług satelitarnych, co jest możliwe także dzięki

16 Ibidem.

17 Ibidem. 
kooperacji ESA z organizacjami kosmicznymi spoza Europy ${ }^{18}$. Celem Agencji jest promowanie i zapewnianie, jedynie w celach pokojowych, współpracy pomiędzy państwami europejskimi w zakresie badań i rozwoju technologii kosmicznych oraz ich wykorzystania dla celów naukowych i tworzenia systemów operacyjnych ${ }^{19}$. Wśród zadań Europejskiej Agencji Kosmicznej należy wymienić realizację wspólnego, europejskiego programu badania i eksploatację przestrzeni kosmicznej, a także umacnianie postępu nowoczesnego oraz konkurencyjnego przemysłu w krajach członkowskich ${ }^{20}$. Zorganizowanie i wprowadzanie europejskiego programu kosmicznego stanowi zadanie Agencji ${ }^{21}$. ESA realizuje dwa rodzaje programów, o których stanowi art. 5 Konwencji. Dzielą się one na programy obowiązkowe oraz programy opcjonalne.

Istotnym aspektem konwencji ESA jest to, że określa ona program naukowy jako oddzielny program obowiązków ${ }^{22}$. Wszystkie kraje będące członkami ESA muszą uczestniczyć i wnosić swój wkład proporcjonalny do ich Produktu Narodowego Brutto (PNB) ${ }^{23}$, gdyż programy te są finansowane ze składek państw członkowskich ${ }^{24}$. Dla roku 2017, w sytuacji Polski stanowi ona równowartość 2,74\% budżetu ESA na programy obowiązkowe ${ }^{25}$. Tymczasem składka w części finansującej programy opcjonalne jest nieobowiązkowa i uzależniona programów kraju członkowskiego ESA, w których zdecyduje się partycypować i w jakiej wysokości zadeklaruje finansowanie swojego udziału w poszczególnych programach opcjonalnych ${ }^{26}$. W roku 2017 polska składka na programy obowiązkowe ESA wyniosła $21,814 \mathrm{mln} €$ i $12,755 \mathrm{mln} €$

${ }^{18}$ Ibidem.

${ }^{19}$ Ibidem.

${ }^{20}$ www.esa.int/pol/ESA_in_your_country/Poland/Poznaj_ESA,[ dostęp: 02-03-2018].

${ }^{21}$ www.esa.int/pol/ESA_in_your_country/Poland/Poznaj_ESA, [dostęp: 15-03-2018].

${ }^{22}$ L. Woltjer, Europe's Quest for the Universe, ESO and the VLT, ESA and other projects, EDP Sciences 2006, s. 163.

${ }^{23}$ Ibidem.

${ }^{24}$ www.esa.int/pol/ESA_in_your_country/Poland/Poznaj_ESA, [dostęp: 01-03-2018].

25 http://www.space24.pl/polska-skladka-do-esa-wzrost-o-17-mln-zl-w-2017-r, [dostęp: 28-03-2018].

${ }_{26}$ http://www.space24.pl/polska-skladka-do-esa-wzrost-o-17-mln-zl-w-2017-r, [dostęp: 28.03.2018 ]. 
na programy opcjonalne ${ }^{27}$. Programy dotyczą między innymi badania przestrzeni kosmicznej oraz budowy i wykorzystania sprzętu służącego takim badaniom, programów naukowych na temat fizyki układu słonecznego, astronomii i fizyki podstawowej, badań technologicznych, programów edukacyjnych oraz pośrednictwa w przepływie informacji o programach kosmicznych państw ${ }^{28}$.

Z kolei programy opcjonalne finansowane są wyłącznie przez kraje, które w nich partycypują. W wyniku negocjacji określany jest współudział każdego z państw, odrębnie dla każdego programu, a ich obręb nie jest definiowany wyczerpująco ${ }^{29}$. Programy opcjonalne dotyczą takich działalności jak: budowa europejskiej rakiety nośnej, loty załogowe, robotyka i programy służące użytkowym zastosowaniom technik kosmicznych, czyli telekomunikacji, obserwacji Ziemi czy nawigacji satelitarnej ${ }^{30}$.

W dniu 12 stycznia 2017 r. podpisano porozumienie, zgodnie z którym do 31 grudnia 2019 roku przedłużono aplikowanie środków przejściowych w odniesieniu do Polski jako członka ESA ${ }^{31}$. Jest to równoznaczne z dalszą możliwością Polski do czerpania zysków przez przedsiębiorców i jednostki naukowe ze stworzonego specjalnie dla Polski Programu wsparcia polskiego przemysłu (Polish Industry Incentive Scheme - PLIIS) ${ }^{32}$. Stanowi to pierwszy raz w historii, gdy Europejska Agencja Kosmiczna wyraziła zgodę się na przedłużenie okresu przejściowego dla państwa członkowskiego. Czechy i Rumunia zakończyły swoje programy po 5 latach od wejścia do ESA ${ }^{33}$.

${ }^{27}$ Ibidem.

${ }^{28}$ www.esa.int/pol/ESA_in_your_country/Poland/Poznaj_ESA, [dostęp: 08.03.2018]

${ }^{29}$ Ibidem.

${ }^{30}$ Ibidem.

${ }^{31}$ https://www.esa.int/pol/ESA_in_your_country/Poland/Polska_utrzymuje_preferencyjne_ warunki_czlonkostwa_w_Europejskiej_Agencji_Kosmicznej, dostęp: 26.03.2018 r.

${ }^{32}$ Ibidem.

${ }^{33}$ http://kosmonauta.net/2018/01/co-czeka-esa-w-2018-roku/, [dostęp: 26.03.2018]. 


\section{Dotychczasowa działalność Europejskiej Agencji Kosmicznej}

Agencja poprzez wystrzelenie satelity teledetekcyjnego ERS-1 w roku 1991 realizowała międzynarodowy program o nazwie „Misja do Planety Ziemia", który rozpoczął się na początku lat dziewięćdziesiątych $^{34}$. Cel programu odnosił się do kompleksowego postrzegania Ziemi jako wielkiego systemu o różnorodnych wzajemnych związkach ${ }^{35}$. W tym samym roku w ramach realizacji programu, został wystrzelony także satelita UARS ${ }^{36}$ przez Amerykańską Agencję Kosmiczną (NASA) oraz w roku 1992 amerykańsko-francuski satelita Topex/Poseidon ${ }^{37}$. Za najbardziej prominentny dla obserwacji astronomicznej dotyczącej badań promieniowania nadfioletowego przed rokiem 2000 okazał się satelita IUE, stanowiący wspólne dzieło ESA, Stanów Zjednoczonych i Wielkiej Brytanii ${ }^{38}$. Wyniesienie satelity na okołoziemską orbitę w roku 1978 i jego funkcjonowanie aż do roku 1996 przyczyniło się do dostarczenia nauce ponad 100 tys. obserwacji astronomicznych oraz przeszło 3500 prac naukowych powstałych z ich wykorzystaniem ${ }^{39}$. ESA przysłużyło się także postępowi w astronomii gamma, dzięki satelicie $\operatorname{COS}-\mathrm{B}^{40}$. Agencja odpowiada także za zbudowanie obserwatorium w podczerwieni ISO ${ }^{41}$, które stanowi następcę IRAS-a ${ }^{42}$ - satelity, który dokonał przeglądu nieba w czterech zakresach podczerwieni ${ }^{43}$.

Z drugiej strony, wśród działań ESA można wskazać również te, które nie do końca poszły po myśli Agencji. Taki przykład stanowi satelita astrometryczny Hipparcos, który stworzony został w celu precyzyjnego określenia odległości, pozycji i ruchu własnego kilkuset tysięcy gwiazd,

${ }^{34}$ M. Królikowska-Sołtan, A. Sołtan (red.), Encyklopedia Geograficzna Świata, Wszechświat, Kraków 2000, s. 50-51.

${ }^{35}$ Ibidem.

${ }^{36}$ Ang. Upper Atmosphere Research Satellite.

${ }^{37}$ M. Królikowska-Sołtan, A. Sołtan (red.), Encyklopedia Geograficzna..., op. cit., s. $50-51$.

${ }^{38}$ Ibidem, s. 62.

${ }^{39}$ Ibidem.

${ }^{40}$ Ibidem, s. 63.

${ }^{41}$ Ang. Infrared Space Observatory.

${ }^{42}$ Ang. Infrared Astronomical Satellite.

${ }^{43}$ M. Królikowska-Sołtan, A. Sołtan (red.), Encyklopedia Geograficzna..., op. cit., s. 64. 
lecz w wyniku awarii technicznej nie został umieszczony w zaplanowanym miejscu ${ }^{44}$. Jednakże okrążanie przez niego Ziemi po wydłużonej elipsie przyczyniło się do powstania katalogu 100 tys. gwiazd ${ }^{45}$, a więc działania tego nie można uznać za totalne niepowodzenie.

Mimo faktu, iż powstanie ESA i Unii Europejskiej dzieli 13 lat, należy zauważyć, że zgodnie z przepisem art. 189 ust. 3 Traktatu o funkcjonowaniu Unii Europejskiej ${ }^{46}$, Unia ustanawia odpowiednie stosunki z Europejską Agencją Kosmiczną. W pierwszych dziesięciu latach polityka kosmiczna nie stanowiła obszaru zainteresowań Unii Europejskiej ${ }^{47}$. Początkowo to państwa członkowskie UE (a wcześniej WE) wdrażały własne projekty w ramach międzyrządowej współpracy, w rezultacie czego powstały European Space Research Organisation (ESRO) i European Launcher Development Organisation (ELDO) w 1960 r., a w efekcie tego Europejska Agencja Kosmiczna w 1975 r. $^{48}$

Jednym z najnowszych osiągnięć ESA jest między innymi budowa i uruchomienie pierwszego na świecie silnika elektrycznego zasilanego rozrzedzonymi cząsteczkami powietrza z górnych warstw atmosfery ${ }^{49}$. Stanowi to idealną podstawę do tworzenia satelitów, które będą w stanie pozostać na bardzo niskich orbitach okołoziemskich przez długi okres. Pierwsza misja ESA w 2018 r. miała miejsce w dniu 2 lutego, gdy zostały wystrzelone dwa satelity ${ }^{50}$. Priorytetowym ładunkiem był chińsko-włoski satelita do obserwacji elektromagnetycznych, które mogłyby wspomóc przewidywanie trzęsień Ziemi ${ }^{51}$. Obecne działania ESA nie koncentrują się wyłącznie na wspomnianej trzeciej, licząc od Słońca planecie Układu Słonecznego. Przykładem tego jest Orbiter ESA Exomars, który został już przygotowany do zainicjowania poszukiwań

\footnotetext{
${ }^{44}$ Ibidem.

${ }^{45}$ Ibidem, s. 65.

${ }^{46}$ Traktat o funkcjonowaniu Unii Europejskiej z dnia 25 marca 1957 r., Dz.U. z 2004 r., nr 90, poz. 864[2].

${ }^{47}$ M. Jankowska, Charakter prawny mapy cyfrowej, Warszawa 2017.

${ }^{48}$ Ibidem.

${ }^{49}$ www.esa.int/pol/ESA_in_your_country/Poland/Pierwszy_na_swiecie_silnik_elektryczny_zasilany_powietrzem, [dostęp: 15-03-2018].

${ }^{50}$ www.esa.int/pol/ESA_in_your_country/Poland/Pierwszy_satelita_ESA_wystrzelony_w_2018_roku, [dostęp: 16-03-2018].

${ }^{51}$ Ibidem.
} 
metanu na Czerwonej Planecie, ponieważ ukończył obniżanie swojej orbity wokół Marsa za pomocą systematycznych zetknięć z górnymi warstwami atmosfery ${ }^{52}$. Exomars Trace Gas Orbiter przybył do Marsa w październiku 2016 roku, w celu badania ewentualnych geologicznych lub biologicznych czynników powodujących tworzenie gazów śladowych w atmosferze planety ${ }^{53}$.

\section{Członkowie Europejskiej Agencji Kosmicznej}

W skład ESA wchodzą 22 państwa członkowskie: Austria, Belgia, Czechy, Dania, Estonia, Finlandia, Francja, Grecja, Hiszpania, Irlandia, Luksemburg, Holandia, Niemcy, Norwegia, Polska, Portugalia, Rumunia, Szwajcaria, Szwecja, Wielka Brytania, Węgry i Włochy ${ }^{54}$. Stosownie do odrębnej umowy, w działalności ESA uczestniczy także Kanada ${ }^{55}$, dzięki czemu kraj ten posiada specjalny status państwa współpracującego z ESA. Na mocy tego porozumienia, Kanadyjska Agencja Kosmiczna uczestniczy $w$ organach decyzyjnych, a także $w$ programach i działalności ESA ${ }^{56}$. Kanadyjskie przedsiębiorstwa mogą ubiegać się i otrzymywać umowy o pracę nad programami ${ }^{57}$. Porozumienie zawiera postanowienie zapewniające o sprawiedliwych korzyściach przemysłowych dla Kanady ${ }^{58}$. Sześć innych państw UE działa na podstawie Umów o Współpracy z ESA, są to: Bułgaria, Cypr, Łotwa, Słowacja, Litwa oraz Malta ${ }^{59}$. Obecnie trwają także rozmowy z Chorwacją.

Polska dołączyła do ESA w listopadzie 2012 r., po wejściu w życie umowy ${ }^{60}$, podpisanej w dniu 31 lipca 2012 r. w Warszawie, pomiędzy

52 www.esa.int/pol/ESA_in_your_country/Poland/Surfowanie_po_atmosferze_ Marsa_zakonczone, [dostęp: 17-03-2018].

${ }^{53}$ Ibidem.

${ }^{54}$ www.esa.int/pol/ESA_in_your_country/Poland/Poznaj_ESA; [dostęp: 02-03-2018].

${ }^{55}$ Ibidem.

${ }^{56}$ European Space Agency and Programs Handbook, Strategic information and contacts, Waszyngton 2016, s. 25.

${ }^{57}$ Ibidem.

${ }^{58}$ Ibidem.

${ }^{59}$ www.esamultimedia.esa.int/multimedia/publications/ESA-Presentation/, s. 4.

${ }^{60}$ Dz.U. z 2013 r., poz. 61. 
Rządem Rzeczypospolitej Polskiej a Europejską Agencją Kosmiczną w sprawie przystąpienia Polski do Konwencji o utworzeniu Europejskiej Agencji Kosmicznej i związanych z tym warunkami. Współpraca Polski z ESA jest długofalowa, gdyż już w 1994 r. Polska była jednym z pierwszych krajów Europy Wschodniej, który podpisał z ESA umowę o współpracy w zakresie pokojowego wykorzystania przestrzeni kosmicznej ${ }^{61}$. Następnie w roku 2007 został podpisany Plan dla europejskich krajów współpracujących, dzięki czemu Polska miała możliwość udziału w kilkudziesięciu projektach badawczych ESA ${ }^{62}$. Należy zauważyć także fakt, że Polska ma długą tradycję lotniczą i przyczyniła się do realizacji wielu projektów naukowych i technologicznych ${ }^{63}$. Polska aktywnie uczestniczyła w kilku misjach naukowych ESA ${ }^{64}$, takich jak Integral, Rosetta, BepiColombo i Solar Orbiter, oraz w działaniach dotyczących obserwacji Ziemi we współpracy z Envisat ${ }^{65}$ i GMES $^{66}$.

Jak można zauważyć na poniższym wykresie według danych z 2016 r., największa liczba pracowników, gdy chodzi o narodowość, wywodzi się kolejno z Francji, Niemiec oraz Włoch. Fakt, iż Kanada nie jest państwem członkowskim ESA i uczestniczy w jej pracach na podstawie odrębnej umowy, nie stanowi przeszkody do aktywnej działalności tego kraju w szeroko rozumianej materii dotyczącej kosmosu. Jak przedstawia wykres, Kanada wyróżnia się większą liczbą pracowników uczestniczących w aktywnościach ESA niż chociażby Polska, Dania czy Finlandia.

${ }^{61}$ ww.esa.int/About_Us/Welcome_to_ESA/ESA_history/Marking_five_years_of_Poland_in_ESA, [dostęp: 05-03-2018].

${ }^{62}$ Ibidem.

${ }^{63}$ Ibidem.

${ }^{64}$ Ibidem.

${ }^{65}$ Nazwa satelity uruchomionego w dniu 1 marca 2002 r., źródło: www.igik.edu.pl/ pl/a/Envisat, [dostęp: 01-03-2018].

${ }^{66}$ Akronim GMES pochodzi od angielskich słów Global Monitoring for Environment and Security, oznaczających Globalny Monitoring Środowiska i Bezpieczeństwa; źródło: www.cbk.waw.pl/?option=com_content\&view=article\&id=170\&Itemid=72, $\quad[$ dostęp: 01-03-2018]. 
Wykres. Liczba pracowników ESA według narodowości (dane za rok 2016)

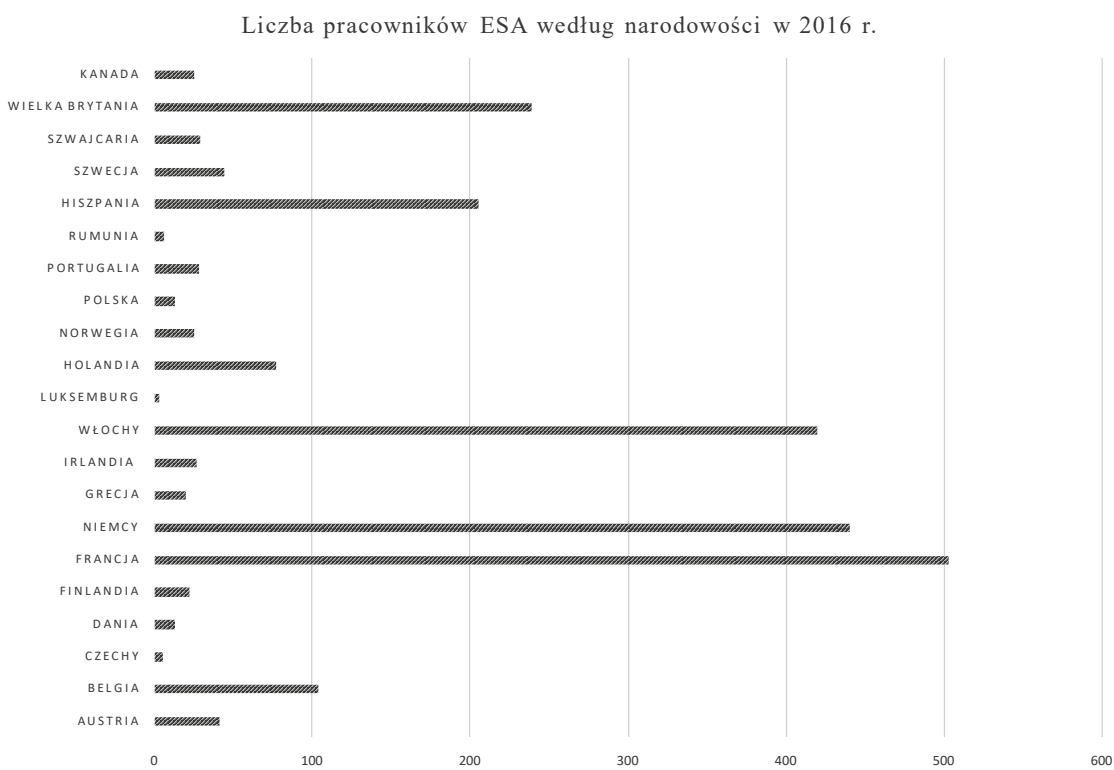

Opracowanie własne na podstawie: www.esamultimedia.esa.int/multimedia/publications/ESA-Presentation/, s. 9.

\section{Podsumowanie}

Przedstawienie najbardziej relewantnych zadań i zagadnień organizacyjno-prawnych ESA ukazuje, że Agencja przyczynia się w dużym stopniu do zgłębienia wiedzy na temat Ziemi oraz Układu Słonecznego. Efektem działań tej organizacji międzynarodowej jest wsparcie postępu technologii i usług satelitarnych, co ESA osiąga nie tylko poprzez współdziałanie z państwami członkowskimi, ale także za pomocą współpracy z pozaeuropejskimi instytucjami kosmicznymi.

Ukazanie działalności ESA z lat dziewięćdziesiątych w porównaniu do najnowszych jej dokonań, wskazuje na znaczne postępy prac naukowców zakresie kreowania i wykorzystywania kosmicznych nowości technologicznych. Między innymi, jak nigdy dotąd istnieje zauważalna możliwość wykorzystania w satelitach silnika elektrycznego zasilanego rozrzedzonymi cząsteczkami powietrza z górnych warstw 
atmosfery, co prawdopodobnie przechodzi najśmielsze wyobrażenia badaczy pracujących w ESA ponad 18 lat temu.

Za bezsprzeczne należy uznać, że przystąpienie państw do Europejskiej Agencji Kosmicznej stwarza podłoże dla nowych możliwości w zakresie badań kosmosu. Na podstawie doświadczeń innych krajów można zauważyć potencjalne korzyści członkostwa w ESA dla Polski, która jest jej członkiem od zaledwie sześciu lat. Po pierwsze Agencja stwarza realne warunki do powstawania miejsc pracy oraz dynamizacji i praktycznego zastosowania nowych technologii. Po drugie, zarówno programy obowiązkowe, jak i programy opcjonalne ESA pozwalają na funkcjonalne zastosowanie technik kosmicznych w telekomunikacji, obserwacji czy rozwoju automatyki. Należy mieć nadzieję, że polscy obywatele znajdą zatrudnienie w ESA w jeszcze większej liczbie niż obecnie, a polskie przedsiębiorstwa oraz jednostki naukowe będą uczestniczyły w przetargach i w tym zakresie będą odnosić sukcesy.

\section{Bibliografia:}

Beckel L. (red.), Mega Cities: The European Space Agency's Contribution to a Better Understanding of a Global Challenge, Geospace Verlag, Salzburg 2002.

Brodecki Z., Majkowska-Szulc S., Pyć D., Tomaszewska M. A., Zużewicz I., Komentarz do Traktatu ustanawiającego Wspólnotę Europejskq, [w:] Traktat o Unii Europejskiej, Traktat ustanawiający Wspólnotę Europejskq z komentarzem, wyd. II, Lexis Nexis 2006, LEX.

European Space Agency and Programs Handbook, Strategic information and contacts, International Business Publications, Waszyngton 2016.

Jankowska M., Charakter prawny mapy cyfrowej, Wyd. Wolters Kluwer Polska, 2017, LEX.

Królikowska-Sołtan M., Sołtan A. (red.), Encyklopedia Geograficzna Świata, Wszechświat, Wyd. Opres, Kraków 2000.

Mitton J., A concise dictionary of astronomy, Oxford University Press Nowy Jork 1991.

Ridpath I., A Dictionary of Astronomy, Oxford University Press, Oxford 2004.

Woltjer L., Europe's Quest for the Universe, ESO and the VLT, ESA and other projects, Les Ulis Cedex: EDP Sciences 2006. 
